\title{
O PLANO DE DEFESA DA BORRACHA: ENTRE O DESENVOLVIMENTISMO E A NEGLIGÊNCIA POLÍTICA AO NORTE DO BRASIL, 1900-1915
}

\author{
THE RUBBER DEFENSE PLAN: BETWEEN \\ DEVELOPMENTALISM AND POLICY NEGLECT \\ IN THE NORTHERN BRAZIL, 1900-1915
}

\author{
Orange Matos Feitosa* \\ Universidade de São Paulo, São Paulo, Brasil, <omfeitosa@bol.com.br> \\ Alexandre Macchione Saes** \\ Universidade de São Paulo, São Paulo, Brasil, <alexandre.saes@usp.br>
}

\begin{abstract}
Resumo. O presente artigo volta-se ao estudo do Plano de Defesa da Borracha instituído pelo governo federal em 1912, como plano de desenvolvimento regional para recuperação econômica da Amazônia. A literatura tratou tal plano como um amplo projeto de transformação regional, mas que por sua grandeza não se efetivou. Compreender sua elaboração e os limites de sua realização é abrir espaço para a discussão das forças políticas existentes na Primeira República brasileira (18891930), tendo em vista a comparação com o bem sucedido e contemporâneo Plano de Valorização do Café. Desse modo, pretende-se analisar a crise da economia gomífera tendo em vista não somente seus determinantes internos, apresentados na historiografia, como também avaliar as causas do restrito apoio do governo da União ao principal produto de exportação da região amazônica.
\end{abstract}

Palavras chave: borracha; Amazonas; política governamental.

Abastract. This paper deals with the Rubber Defense Plan, established by the Brazilian government in 1912, as a regional plan of development to the economic recovery of Amazon. The literature addressed the plan as a broad project of regional transformation, involving investments in transport, tax cuts, immigration, education, health, among other sectors; but for his greatness, the project failed to materialize. Understand the constitution of the Plan and its limits is to open a scenario for the discussion of the political forces in the First Brazilian Republic (1889-1930), especially in comparison with the Coffee Defense Plan. Thus, we intend to analyze the rubber economic crisis not only through the internal determinants, presented in historiography, but also showing the limited of federal government support to the main export Amazon product.

\footnotetext{
* Bolsista da Fundação de Amparo à Pesquisa do Estado do Amazonas.

** Pesquisa financiada pela Fundação de Amparo à Pesquisa do Estado de São Paulo.
}

Am. Lat. Hist. Econ., año 20, núm. 3, septiembre-diciembre, 2013, pp. 138-169 
Key words: rubber; Amazonas; government policy.

Fecha de recepción: noviembre de 2012. Fecha de aceptación: febrero de 2013.

De mais a mais, nenhuma razão haveria de se recusar à Amazônia o que se tem prodigalizado larga manu aos estados do sul, notadamente o de São Paulo. De fato, não se justifica que tendo sido destinada quantiosa soma para a proteção do café, que, aliás, já tem sido objeto de sucessivos favores da União, se proceda de modo diverso quanto à borracha que merece ser amparada com o mesmo, senão maior carinho...

$\mathrm{E}$

m 1906, com a tendência de valorização da moeda nacional e, especialmente, com uma florada dos cafezais de proporções até então desconhecidas, organizou-se o Convênio de Taubaté, isto é, um plano para defesa do setor, sob a liderança dos estados produtores e, mais tarde, com apoio do governo federal. O Plano de Valorização do Café previa a compra e estocagem da produção excedente a fim de retirá-lo do mercado para assegurar seu preço. O sucesso do Convênio de Taubaté, já demasiadamente explorado na literatura econômica brasileira, tanto em função da recuperação dos preços do produto no mercado mundial, como na sustentação financeira da política econômica cafeeira, abriu espaço para a constituição de mais três planos de defesa do café durante a Primeira República, sendo o último, de 1924, um Plano de Defesa Permanente. ${ }^{2}$

Em 1912, seis anos mais tarde da primeira intervenção do governo no mercado de café, era a vez dos representantes do Amazonas e do Pará de exigirem uma intervenção no mercado, mas agora da borracha (ver mapa 1). Com a finalidade de auxiliar a economia local num momento de crescente concorrência internacional, o Plano de Defesa da Borracha não somente foi elaborado, como foi amplamente defendido pela Câmara dos Deputados e aprovado no governo do presidente Hermes da Fonseca (1910-1914). O plano que transpunha medidas apenas para o setor da borracha, tocando em questões como transporte, indústria, impostos, saúde e imigração, chegou a instituir uma Superintendência da Borracha. Entretanto, diferentemente do Plano de Defesa do Café, daquele projeto apro-

${ }^{1}$ Carneiro, Borracha, 1918.

${ }^{2}$ Para o Plano de Defesa do Café, ver Delfim, Problema, 2009, caps. 2 e 3; Holloway, Vida, 1978, caps. III e IV, e Perissinotto, Classes, 1994, cap. 2. 


\section{MAPA 1. BRASIL POLÍTICO, 1855}

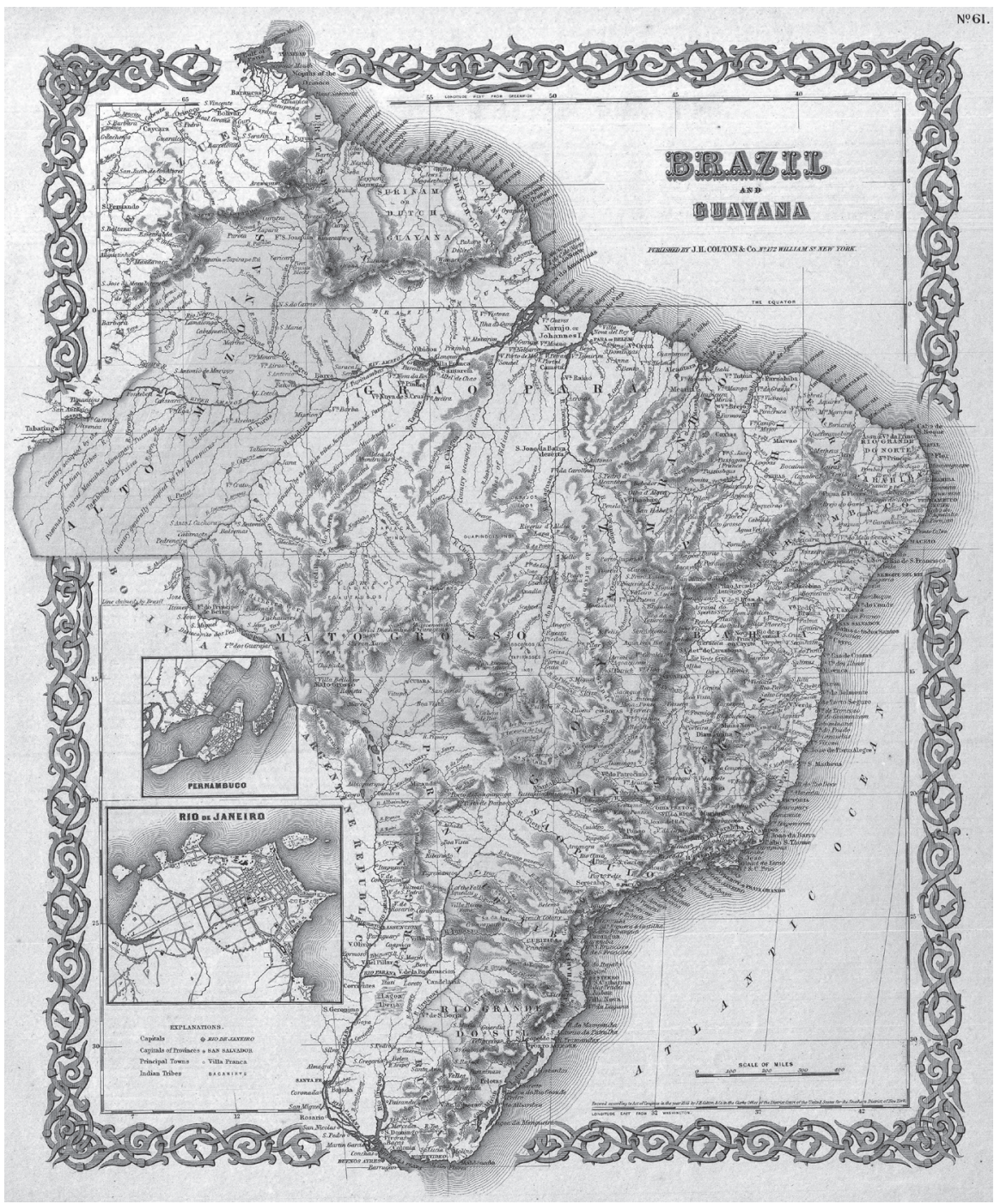

Nota: as províncias do Amazonas e Pará são as duas grandes regiões no norte do país.

Fonte: Colton, Colton's, 1855. 
vado para apoiar a valorização econômica nortista, pouco saiu do papel. O resultado previsível e conhecido foi a crise da economia do látex, já na década de 1910, e a perda do papel da produção amazônica no mercado internacional.

Nos estudos voltados para a economia da borracha o Plano de Valorização da Borracha, decretado em 1912 no governo de Hermes da Fonseca, não foi tomado como tema específico. ${ }^{3}$ Isto porque possivelmente esses estudos se detiveram na formação e expansão da economia do látex como um todo. ${ }^{4} \mathrm{Em}$ alguns casos, por outro lado, ao enfatizarem a crise econômica da borracha, mencionavam o Plano, mas sem analisá-lo, imputavam o não êxito ao descaso do governo da União com os estados do Norte. Neste sentido, aprofundar a análise dessas versões pode contribuir para o entendimento da evolução da economia nortista e de sua crise, assim como o papel do Plano de Defesa da Borracha na economia do Norte do Brasil. ${ }^{5}$

O presente artigo pretende, portanto, se voltar ao estudo do Plano de Defesa da Borracha, que foi lançado num momento estratégico -ou mesmo crítico- para a recuperação da economia amazônica. Compreender sua elaboração e os limites de sua realização é abrir espaço para a discussão das forças políticas existentes na Primeira República brasileira, especialmente tendo em vista a comparação com o bem-sucedido e contemporâneo Plano de Valorização do Café. Para tanto nos valemos não somente do debate historiográfico sobre o tema, como também analisamos os debates parlamentares referentes ao Plano, compreendendo assim a posição dos personagens envolvidos na elaboração das diretrizes para a recuperação econômica do Norte do país. Em suma, o presente artigo busca descortinar o Plano de Defesa da Borracha, apresentando suas propostas e a posição dos atores que estiveram ligados a tentativa de solução da crise gomífera.

\footnotetext{
${ }^{3}$ Dentre os poucos trabalhos que retratam o Plano de Defesa da Borracha, ver Weinstein, Borracha, 1993; Santos, História, 1980, e Pinto, Política, 1984.

${ }^{4}$ No que diz respeito à historiografia brasileira, onde a dimensão econômica foi mais explorada, ver Cano, Raízes, 1977; Cardoso e Müller, Amazônia, 1977; Carone, República, 1975; Furtado, Formação, 1990; Prado, Formação, 2004, e História, 1990; Prado e Capelato, "Borracha", 1975, e Fausto, Historia, 1975.

${ }^{5}$ Parte dos historiadores em Manaus não se interessou por aprofundar sobre o tema da economia regional, deixando para os leitores posteriores apenas um silêncio já sintomático na história do Amazonas e consequentemente sobre a crise econômica da borracha, a exemplo: Costa, "Quando", 1997; Dias, Ilusão, 2007; Pinheiro, Cidade, 1999; Santos, Rebelião, 2001; Bittencourt, Corographia, 1985; Loureiro, Sintese, 1978, e Grande, 1985; Monteiro, Negritude, 1990; Reis, História, 1989, e Seringal, 1997. Antonio Loureiro, por outro lado, é um dos poucos autores locais, como veremos, a se preocupar com a questão do Plano de Defesa.
} 


\section{ASCENSÃO E CRISE DA ECONOMIA DA BORRACHA}

Apesar de oferecer conhecida aplicação ainda no período colonial, ou mesmo inclusive no período pré-colonial, a borracha somente apareceu como produto com potencial comercial em meados do século XIX. Dois marcos para a comercialização da borracha são bastante conhecidos: a descoberta do processo de vulcanização da goma por Goodyear (1839) e Hancock (1842) e, para a definitiva expansão de sua demanda, a utilização do produto para a indústria automobilística na década de $1890 .{ }^{6}$ Assim, na inexistência de produções mundiais intensivas, a atividade seringalista brasileira se aproveitaria dessa conjuntura para em fins dos século XIX apresentar tremendo impulso.

É neste contexto que a borracha brasileira passaria por um "ciclo" auge de produção entre 1890 e 1910. No que diz respeito ao comércio mundial, a região Amazônica seria nestes vinte anos, de longe, o principal centro fornecedor da goma aos maiores mercados mundiais. Por outro lado, no que diz respeito à economia brasileira, durante a primeira década dos novecentos a borracha alcançaria entre $20 \%$ e $40 \%$ do valor total dos produtos exportados pelo país, mantendo posição de segundo principal produto exportado, apenas atrás do café (ver gráfico 1).

Assim, a evolução da extração da borracha atestava sua importância na economia regional e, também, nacional -mesmo que esta importância nem sempre tenha sido abordada com a devida atenção. ${ }^{7}$ Nas décadas de 1850 e 1860, ainda sem expressão no valor das exportações nacionais (2.3\% e 3.1\%, respectivamente), o produto passou a concentrar as atividades da Bacia Amazônica, liquidando crescentemente com outras culturas locais como de café, tabaco e algodão. ${ }^{8} \mathrm{~A}$ rápida e elevada rentabilidade auferida pelo negócio da borracha atraia capital e trabalho para a região. Afinal, por exemplo, a exportação do estado do Amazonas, em 1906, foi dividida entre 10500 toneladas de borracha, 2600 de castanha e, bastante atrás, 200 toneladas de peixe. ${ }^{9}$ Pode-se dizer que, a atividade agropecuária do Norte teria avançado quase para o completo extrativismo do látex, criando elevadas rendas para a região. Este rentável negócio, consequentemente, transformava a imagem de algumas cidades amazônicas, ampliava

${ }^{6}$ Ver Prado e Capelato, "Borracha", 1975, p. 288, e Pinto, Política, 1984, p. 33.

${ }^{7}$ Celso Furtado, por exemplo, não leva em conta a riqueza acumulada no auge da expansão da economia do látex: enfatiza a atividade como uma solução de emergência, sem bases racionais de produção, cujo resultado foi um "enorme desgaste humano", absorvendo a mão de obra Nordestina e não a tornando trabalhadora assalariada. Furtado, Formação, 1990, pp. 129-135.

${ }^{8}$ Prado e Capelato, "Borracha", 1975, p. 299.

${ }^{9}$ Lino Aguiar \& Cia, Almanach, 1909, p. 6. 


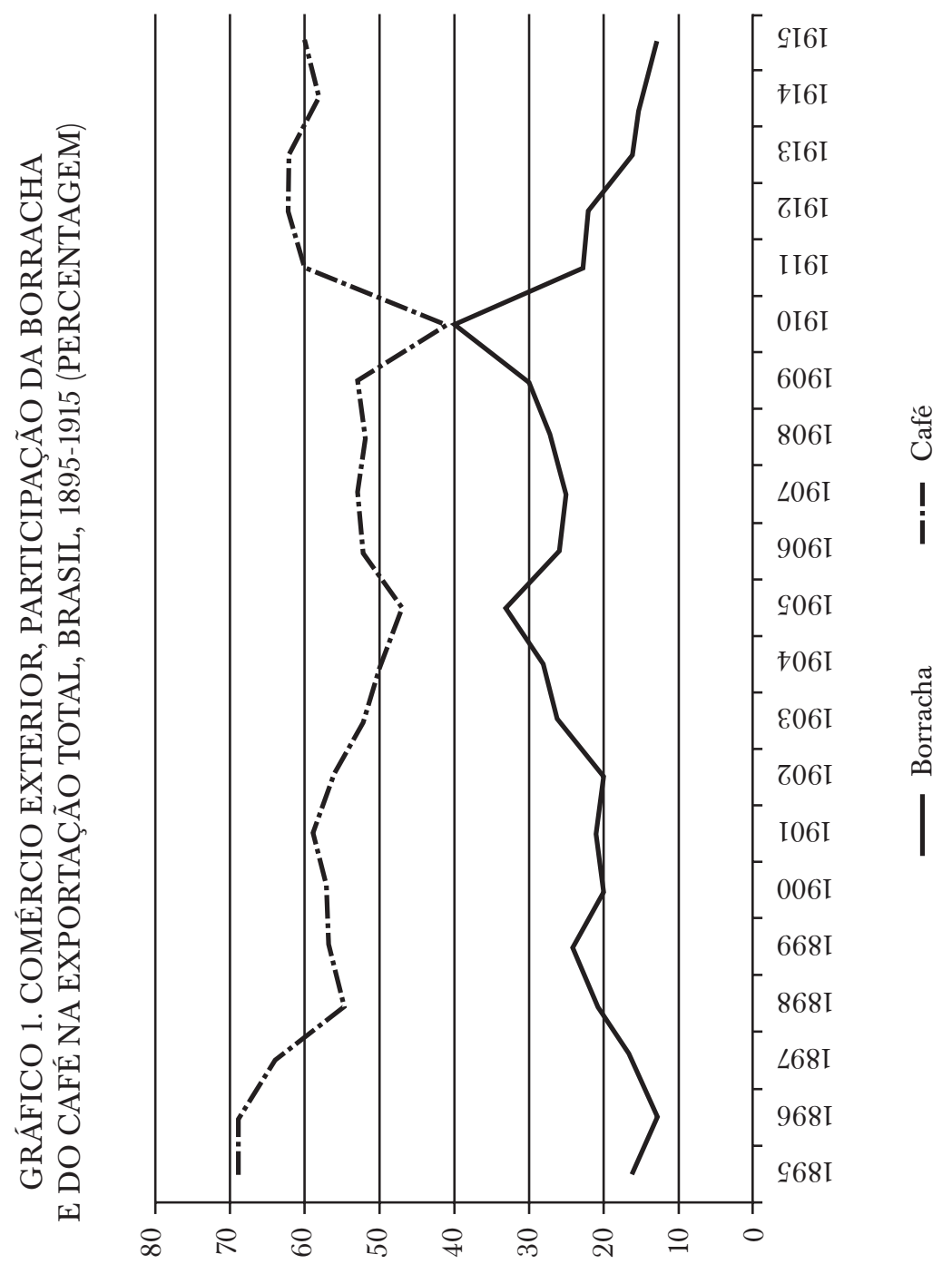

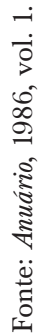


o processo de migração de trabalhadores para a região ${ }^{10}$ e desenvolvia todo um setor de serviços urbanos. ${ }^{11}$

Na historiografia, o rápido processo de urbanização das cidades de Belém e Manaus -decorrente dessa expansão dos negócios da borracha-, foi usualmente lembrado como forma de destacar o gasto luxuoso das elites locais. Profundo investimento urbanístico na região, com o Teatro Amazonas e o Teatro da Paz, respectivamente nas capitais regionais de Manaus e Belém, eram os típicos personagens dessa transformação. Processo esse lembrado de maneira exagerada por autores como Caio Prado Júnior:

O símbolo máximo que ficará desta fortuna fácil e ainda mais facilmente dissipada é o Teatro Municipal de Manaus, monumento em que à imponência se une ao mau gosto, [...]. É claro que desfeito o castelo de cartas em que se fundava toda esta prosperidade fictícia e superficial, nada sobraria dela. Em poucos anos [...] a riqueza amazonense se desfará em fumaça. Sobrarão apenas ruínas [...]. O drama da borracha brasileira é mais assunto de novela romanesca que de história econômica. ${ }^{12}$

Porém, tal processo de rápida transformação econômica com uma restrita expansão e diversificação das atividades produtivas revelaria duas facetas preocupantes desta economia em crescimento: uma modernização urbana, cujo custo era não somente a profunda concentração da renda -com o aviamento como relação de trabalho que impedia o assalariamento e a formação do mercado interno regional- ${ }^{13}$ como também a corrupção administrativa por conta das elevadas rendas. ${ }^{14}$

Apesar da polêmica existente quanto aos resultados obtidos pela atividade, às formas de aplicação dos ganhos extraídos da economia do látex e aos custos sociais desse processo, não há dúvidas quanto ao papel desempenhado pela borracha nas rendas dos estados do Amazonas, do Pará e, até mesmo, do território do Acre -adquirido em negociação da Bolívia em $1903 .{ }^{15}$ Essas rendas acompanharam a evolução das exportações do

${ }^{10}$ Para o deslocamento da mão de obra nordestina, ver Furtado, Formação, 1990.

${ }^{11}$ Para a expansão dos serviços urbanos locais, ver Dias, Ilusão, 2007.

${ }^{12}$ Prado, História, 1990, pp. 240-241.

${ }^{13} \mathrm{O}$ aviamento era uma forma de relação entre comerciantes da borracha e os trabalhadores dos seringais, cuja base de troca era quase o escambo, ver Cano, Raízes, 1977, pp. 88-92, e Santos, História, 1980, p. 300.

${ }^{14}$ Loureiro, Grande, 1985, p. 247.

${ }^{15} \mathrm{O}$ tema das rendas estaduais foi bastante controverso na disputa entre os estados do Amazonas e do Pará, quando em 1900 determinou-se que toda a borracha produzida em território amazonense, por conta dos esforços do governador Silvério Nery, deveria realizar sua alfândega em Manaus. Ver Santos, História, 1980; Loureiro, Grande, 1985, e Weinstein, Borracha, 1993. 
produto, o que conferiu uma dependência perigosa dos governos locais aos negócios da borracha (ver gráfico 2).

O gráfico 2 é enfático: a queda das exportações de borracha -e de sua participação nas rendas nacionais totais- reduziu para menos da metade as rendas estaduais em menos de uma década. Isso explica os esforços e/ou interesses do diplomata Barão do Rio Branco para a aquisição do território do Acre no início do século Xx. A região era detentora de representativos seringais, compondo parte expressiva das exportações de borracha para o mercado mundial. Por isso o interesse do Bolivian Syndicate ${ }^{16}$ das disputas entre Amazonas e Pará para controle de sua economia. A incorporação do território ao Brasil em 1903, por meio do Tratado de Petrópolis e via negociações com a Bolívia, somente resolveria uma das questões para os políticos nortistas. Afinal, com a aquisição do território, quem administraria as receitas do território? O governador amazonense, Silvério Nery (1900-1903), apostava que o recém-incorporado território deveria ser controlado por Manaus. Entretanto, a decisão tomada pelo governo federal foi mantê-lo como território nacional, sem beneficiar qualquer estado.

A determinação do governo não resolveria o impasse sobre as rendas do látex. A redução das receitas redundaria, inclusive, em conflito armado entre Pará e Amazonas. Em 1915 o governo do Amazonas ressaltava "o abuso de vapores do porto de Belém" de seguirem para o Acre -e viceversa- sem paradas em Manaus, se furtando da "fiscalização das repartições nas fronteiras do Estado", ${ }^{17}$ gerando danos à receita do Amazonas. No ano seguinte, o governo amazonense enviou um destacamento policial para região do Alto Tapajós para suposta proteção do território e dos postos de coletoria da extração acreana, alegando que os impostos sobre a produção do látex dali exportada pertenciam ao Amazonas. Por sua vez, o governo paraense salientava que as arrecadações daquela região reclamada pelo Amazonas eram "nulas". ${ }^{18}$ Em abril de 1916, os policiais de ambos estados se enfrentaram resultando na morte de praças. Wenscelau Braz, o então presidente da república, teria que intervir para pôr fim ao conflito. A situação permaneceu tensa e, em 1917, Alcantara Bacellar, governador do Amazonas, enviou documento solicitando ao Pará um modus vivendi entre ambos estados enquanto aguardassem a sentença da justiça federal. O governo solicitava também intervenção na Associação Comercial do

${ }^{16}$ Grupo anglo-norte americano que "arrendou” o território da Bolívia em 1901 para extração da goma, foi encampado mais tarde pelo governo Rodrigues Alves por 126000 libras. Ver Weinstein, Borracha, 1993, p. 236.

${ }_{17}^{17}$ Mensagem, 1915, p. 86.

${ }^{18}$ Mensagem, 1916, p. 37. 


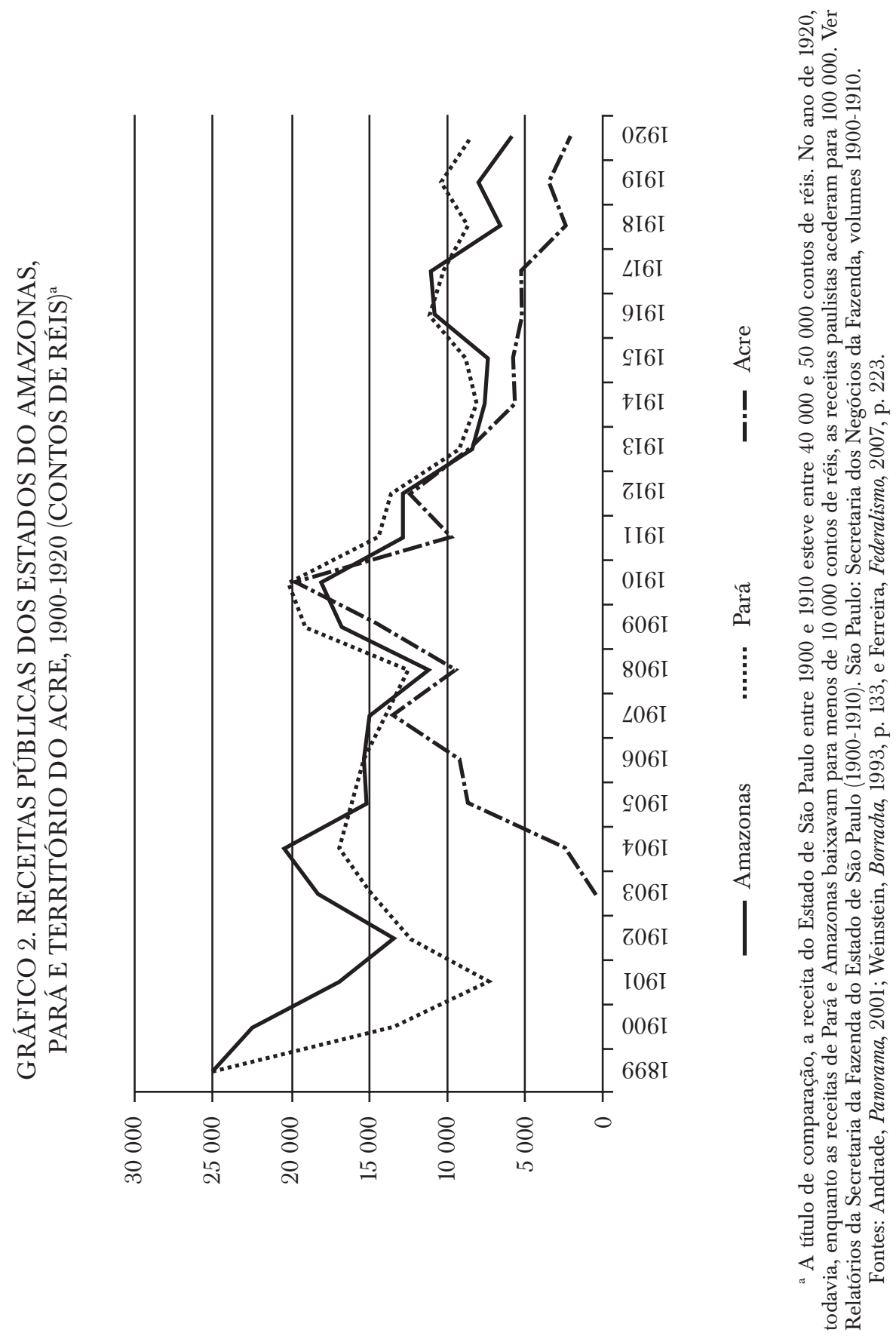


Pará para que esta atuasse junto aos comerciantes e "armadores" paraenses exigindo que vapores oriundos do Acre fizessem escala em Manaus. ${ }^{19}$

Em resposta, a Associação Comercial do Pará trouxe à tona a lei ${ }^{20}$ criada por Silverio Nery que lhes causou graves prejuízos ao exigir que a goma elástica extraída no Amazonas fosse pesada em Manaus fazendo com que as importantes casas exportadoras e aviadoras de Belém se transferissem para capital do Amazonas. Enfatizava a associação em nome dos comerciantes paraenses: "a lei em questão incide sómente sobre a borracha, abrindo portanto para esse gênero uma excepção odiosa". ${ }^{21} \mathrm{O}$ relato da Associação Comercial deixou implícito que o embate armado pela região do Alto Tapajós não tinha a ver com o território em si, mas mais uma vez com as rendas da borracha transportada pelos vapores que saiam direto do Acre sem subir o rio para Manaus, seguindo direto para Belém. Era a manifestação de uma economia em crise, que sofria com a queda de sua principal receita.

Resumindo, os ganhos financeiros extraídos dos negócios da borracha, antes da concorrência asiática, eram evidentes para os grandes sindicatos internacionais, para os grandes comerciantes locais e, inclusive, para os governos estaduais e federal. Entretanto, a comercialização da goma foi tomada rapidamente por grandes casas estrangeiras: em 1911, 80\% das exportações para Europa e Estados Unidos realizou-se por meio de cinco companhias estrangeiras. Ademais, somente o grupo Gruner \& Cia./Dusendsehon, Zarges \& Cia. controlava praticamente $36 \%$ das exportações. ${ }^{22}$

Isso significa que parte considerável do mais importante negócio amazônico era controlada pelos interesses e projetos destas casas comerciais, especialmente as importadoras em Nova York e Liverpool. Para Nelson Prado Alves Pinto esse modelo aprofundava a dominância do capital comercial e ampliava a vulnerabilidade de economia local: "criou-se, assim, uma economia onde os principais recursos se concentravam no comércio exportador e importador, bem como nos serviços de transporte e financiamento destas operações" ${ }^{23}$ Logo, grande parte do excedente gerado pela economia foi quase na sua totalidade desviado para outras regiões, fossem elas internas ou externas ao mercado nacional, ou mesmo "empregado em

${ }^{19}$ Mensagem, 1917, pp. 51-69.

20 "Lei Estadual Amazonense núm. 449 de 8 de outubro de 1900", in Ferreira, Federalismo, 2007, p. 213.

${ }^{21}$ Mensagem, 1917, p. 57.

${ }^{22}$ Essa hierarquia era semelhante na economia cafeeira paulista, em que entre as dez maiores casas comerciais exportadoras, apenas uma era nacional. Entretanto, seguindo a leitura da Wilson Cano, foi possível criar um complexo exportador em São Paulo, que diversificava a economia, criando uma elite nacional com outros tantos negócios além das exportações. Para as empresas exportadoras, ver Fausto, Historia, 1975. Para a ideia de complexo cafeeiro, ver Cano, Raizes, 1977.

${ }^{23}$ Pinto, Política, 1984, p. 23. 


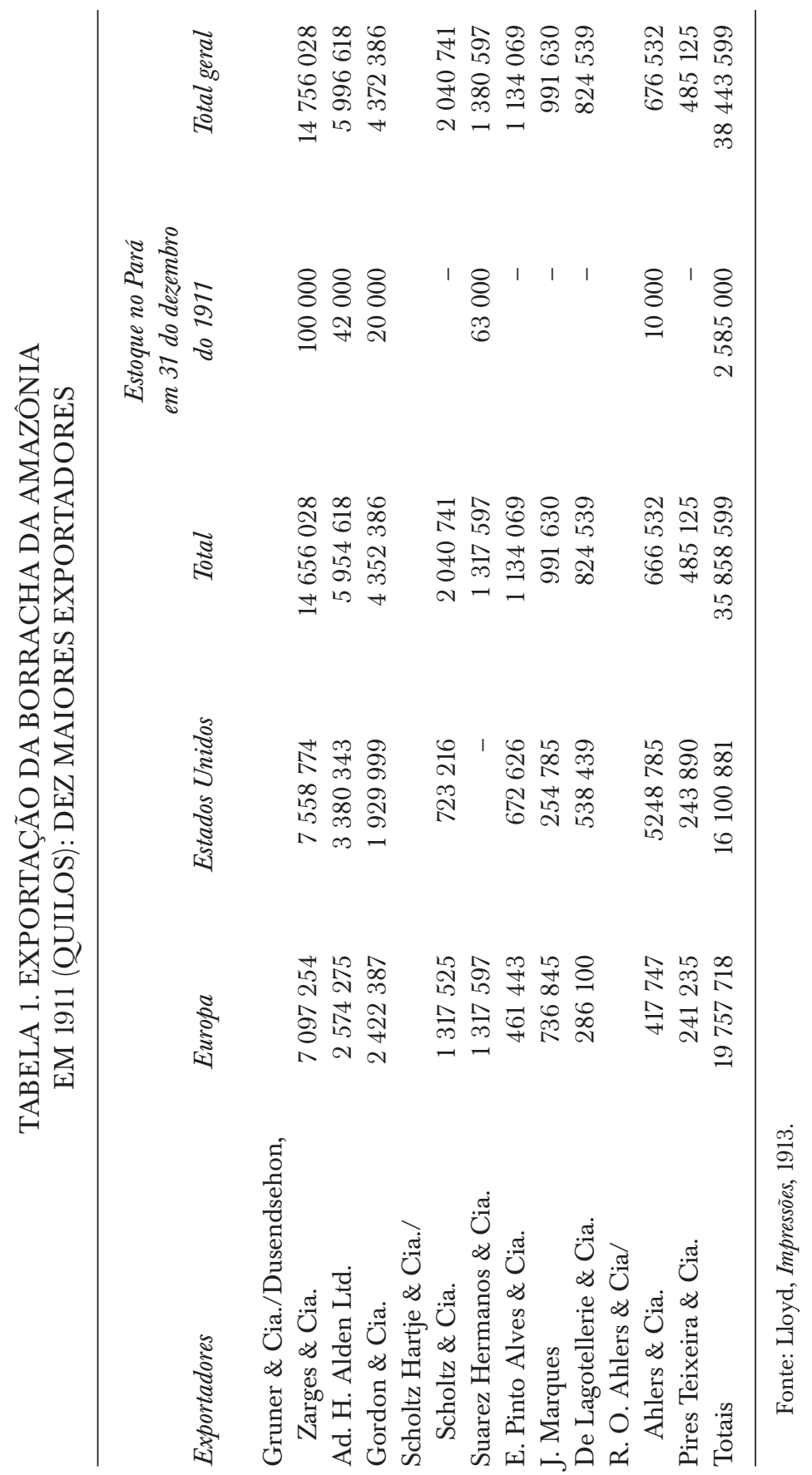


consumo suntuário".${ }^{24} \mathrm{O}$ pouco que sobrava para a economia local investir foi consumido em obras públicas de modernização e demais serviços urbanos, não criando outras formas de investimentos produtivos. ${ }^{25}$

Warren Dean ao reforçar o discurso de crise, calcula que os governos teriam gasto 241000 contos de réis entre 1890 e 1912 no "embelezamento de suas capitais" e no "pagamento dos políticos locais" ${ }^{26}$ sem investimentos produtivos, portanto. Wilson Cano, por sua vez, comparando o vigor do complexo paulista com a riqueza da economia da borracha amazônica, se surpreende como uma população que representava apenas $4 \%$ da população brasileira e conseguia concentrar 10\% das importações do país em 1900. Eram produtos que garantiam o consumo da elite, mas também de abastecimento básico da população: em 1913, a região importava 28\% do total de arroz importado pelo país, 35\% do feijão e 35\% do milho. ${ }^{27} \mathrm{Ou}$ seja, a riqueza que era produzida pela atividade principal escorria para outras regiões.

Vale ressaltar que essa fase de ostentação estava condenada ao seu fim: a competição com as produções asiáticas, especialmente do Ceilão e Malásia, já evidenciada no início do século $\mathrm{Xx}$, tornou-se crítica na primeira década de $1920 .^{28} \mathrm{O}$ baque foi rápido: levou cerca de quinze anos para a produção de borracha de região Amazônica ter reduzida sua participação no mercado mundial de sessenta para 5\% (ver tabela 2).

Neste sentido, a historiografia buscaria encontrar a razão fundamental desta crise na economia amazonense, considerando sua incapacidade de se manter no mercado mundial por conta da competição asiática. Para a interpretação de Celso Furtado, não somente a região não conseguia construir seu mercado interno por conta das relações de trabalho, como considerava a produção amazonense distante de uma racionalidade econômica que seria implementada pela Inglaterra na Ásia.

Warren Dean, por seu turno, indicou o ano de 1911 como o marco da crise: era o fim dos investimentos estrangeiros na região. ${ }^{29} \mathrm{O}$ autor, seguindo as pegadas do discurso dos investidores estrangeiros contemporâneos, considerou que a burguesia local não tinha capacidade/condições de sozinha retomar o crescimento de atividades. ${ }^{30}$ Nas palavras de Dean:

${ }^{24}$ Ibid., p. 41.

${ }^{25}$ Ibid., p. 44.

${ }^{26}$ Dean, Industrialização, 1971, p. 81.

${ }^{27}$ Cano, Raizes, 1977 , p. 58.

${ }^{28}$ Para a saída das sementes das seringueiras da região Amazônica e formação das plantações asiáticas, ver Dean, Luta, 1989, cap. 2.

${ }^{29}$ Ibid., p. 82.

${ }^{30}$ Como Barbara Weinstein relata, a força de trabalho era considerada primitiva, ou no limite, como apresentada por um investidor do Denver, "uma força de trabalho de macacos treinados". Weinstein, Borracha, 1993, pp. 190-209. 
TABELA 2. PARTICIPAÇÃO BRASILEIRA NA PRODUÇÃO MUNDIAL DE BORRACHA, 1900-1922

\begin{tabular}{cccc}
\hline Anos & Brasil & Total mundial & $\begin{array}{c}\text { Percentagem do } \\
\text { Brasil no total mundial }\end{array}$ \\
1900 & 26750 & 44808 & 59.6 \\
1905 & 35000 & 57001 & 61.4 \\
1910 & 40800 & 95611 & 42.6 \\
1915 & 37220 & 173442 & 27.0 \\
1922 & 21775 & 409676 & 5.3 \\
\hline
\end{tabular}

Fonte: Pinto, Política, 1984, p. 40.

existia na região uma "burguesia estúpida e incompetente" e "trabalhadores simetricamente comodistas e estáticos". O autor não levou em conta, contudo, que parte da elite local investiu no cultivo da seringueira, cultivo logo abandonado devido à pressão do mercado internacional que visava o imediatismo dos lucros. ${ }^{31}$ Considerava, ainda, que mais dois fatores se colocavam centrais para compreender a crise na região: a ausência de agentes agrícolas do governo no exterior e falta de apoio do governo federal com a crise econômica local: "A espantosa indiferença do governo federal para com a sorte da economia amazônica parece quase suicida, considerando-se que a região, com apenas $1 / 25$ da população do país, havia proporcionado um sexto da renda nacional. No período de 1890 a 1912 o governo federal coletou nos estados do Amazonas e do Pará 656000 contos de réis a mais do que gastou." ${ }^{\prime 2}$

$\mathrm{Na}$ leitura de Nelson Pinto, por sua vez, tanto a cultura da borracha como uma potencial diversificação da economia esbarravam na falta de infraestrutura local. ${ }^{33} \mathrm{O}$ problema não seria mais os produtores locais. A concentração da renda e dos negócios em setores como comércio e prestação de serviços acabava por limitar a disseminação da riqueza local. O que para Wilson Cano representava a dificuldade de constituição de um complexo econômico regional integrado. ${ }^{34}$

\footnotetext{
${ }^{31}$ Vale considerar que Warren Dean, ao escrever sobre a experiência da formação da indústria de São Paulo, dará destaque aos imigrantes (ou mesmo a burguesia ligada ao comércio importador) neste papel de transformação da economia. Enfim, em sua análise o caráter do indivíduo assume significado preponderante. Dean, Industrialização, 1971.

${ }^{32}$ Dean, Luta, 1989, p. 80.

${ }^{33}$ Pinto, Política, 1984.

${ }^{34}$ Cano, Raizes, 1977 , cap. I. 2.1.
} 
No que diz respeito aos estudos realizados por pesquisadores locais, por outro lado, entre os motivos que conduziram a crise da economia da borracha, encontram-se apenas duas importantes contribuições de Antonio Loureiro. ${ }^{35}$ Os demais estudos reforçaram o esquecimento e o silêncio sobre a crise da borracha, encerrando a economia regional na nostálgica opulência do látex ou nos conflitos urbanos entre trabalhadores e patrões. ${ }^{36}$

Em seu livro A grande crise (1908-1916), Antônio Loureiro ao responder o porquê da "indústria extrativa" da borracha ter entrado em crise, apontou novos elementos para o debate, sinalizando que a Amazônia não progrediu ao "nível de São Paulo" devido ao desinteresse do governo federal pela região. Assim, os impostos e as divisas recebidas por conta da economia "amazônica" eram aplicados no "Sul". No mais, o oligopólio das exportações, a desonestidade e corrupção dos governos estaduais, a "insalubridade reinante" e as "dimensões continentais" da Amazônia, não permitiram que a economia de exportação da borracha se consolidasse. ${ }^{37}$ Destacando que nos anos de 1907 e 1908 a região teria sofrido uma "subcrise" por conta concorrência asiática, reafirmava que a grande crise se deu "entre 1908 e 1916". ${ }^{38}$ Porém, mesmo neste cenário tanto de crise econômica como do "aparelho estatal", lucraram "os exportadores" e os "intermediários especuladores das bolsas de Nova York e Londres". Para o autor, estes eram os maiores responsáveis pela "instabilidade" da economia regional: "Embora [...], seringueiros, seringalistas e aviadores, principalmente na época áurea da exclusividade, também desviaram recursos locais para suas regiões de origem, bloqueando o desenvolvimento desta área produtora." ${ }^{39}$

Em 1994, Antonio Loureiro publicou Tempos de esperança-Amazonas (1917-1945), reconstruindo o argumento sobre o período de pós-crise da economia gumífera, sentenciou que a "grande crise" que dominou a Amazônia se deu por conta do "desinteresse" do capital internacional, mas especificamente, da Inglaterra que controlava a região desde 1875 . No século XX, a preocupação fundamental do país passou a ser seus investimentos

${ }^{35}$ Loureiro, Grande, 1985, e Tempos, 1994.

${ }^{36}$ Ver os trabalhos de Bittencourt, Corographia, 1985; Costa, "Quando", 1997; Dias, Ilusão, 2007; Santos, Vivência, 2004; Monteiro, Negritude, 1990; Pinheiro, Cidade, 1999, e "Folhas", 2004; Reis, Rotina, 1965, e Seringal, 1997, e Santos, Rebelião, 2001.

${ }^{37}$ Loureiro, Grande, 1985, p. 247.

${ }^{38}$ De acordo com o Jornal O Rio Negro, Manaus, 27 de novembro de 1897, ano I, núm. 121, Seção de Informações/Cotações do Jornal. Os valores em réis para o período de 22 a 27 de novembro, foram: cacáu, $\mathrm{kg} 1$ 150; castanha, hectolitro 24 300; guaraná, $\mathrm{kg} 5$ 000; goma elástica fina, $\mathrm{kg} 8$ 810; goma elástica entre fina, $\mathrm{kg} 8$ 031; goma elástica Sernamby, $\mathrm{kg} 4$ 810; Pirarucu, kg 1000 . Por estes valores podemos perceber o porquê de Loureiro e demais autores considerarem a exportação do látex, como o produto que conduziria o Amazonas ao desenvolvimento.

${ }^{39}$ Loureiro, Grande, 1985, pp. 15-16. 
nos seringais orientais. ${ }^{40}$ Apesar dos relatos mecanicistas que acentuaram certos aspectos de forma isolada, este foi o único autor amazonense que tematizou os motivos geradores da crise econômica que tomou conta do vale amazônico. $\mathrm{O}$ autor não tentou escapar do consenso comum aos testemunhos à época que reforçaram o discurso de desleixo do governo federal para com a Amazônia e o persistente investimento nos estados do Sul, especialmente em São Paulo. Contribuiu para a constituição de uma memória circular amarrada em argumentos elaborados pelos parlamentares amazonenses que supervalorizaram o antagonismo político entre estes estados, para acobertar o posicionamento tardio de defesa, desinteresse velado e conciliatório entre o capital internacional e as elites extrativistas.

O problema fundamental da região era não ter diversificado suficientemente sua produção interna e, por isso, tornou-se dependente fundamentalmente das rendas extraídas da exportação da borracha. Neste sentido, em 1912 buscou-se solucionar a questão da reinserção da borracha amazônica no mercado internacional por meio do Plano de Defesa da Borracha. Este tinha surgido como meio para recuperar uma economia prenhe de contradições e que certamente permaneceria enfrentando as conseqüências de políticas públicas limitadas e de uma estrutura produtiva arcaica.

\section{O Plano de Defesa da Borracha}

Em 1912, diante tamanha crise econômica e política que se colocava no horizonte da economia gomífera -com a queda dos preços de 15000 réis para 5000 réis e sete projetos engavetados ${ }^{41}$ na Câmara dos Deputados em menos de cinco anos- finalmente o Congresso Nacional promulgou o Decreto núm. 2.543A de 5 de janeiro de 1912, que: "Estabelece medidas destinadas a facilitar e desenvolver a cultura da seringueira, do caucho, da maniçoba e da mangabeira e a colheita e beneficiamento da borracha extrahida dessas arvores e autoriza o poder executivo não só abrir os créditos precisos á execução de taes medidas, mas ainda a fazer as operações de crédito que para isso forem necessárias." ${ }^{22}$

Tal indicação foi determinada pelo Decreto núm. 9.521 de 17 de abril de 1912 que aprovava o regulamento para a execução das medidas e serviços previstos pela lei núm. 2.543A, de 5 de janeiro de 1912, "concernente

${ }^{40}$ Loureiro, Tempos, 1994, p. 9.

${ }^{41}$ Ver respectivamente os projetos de Passos de Miranda (1906), Menezes Doria (1906), Pedreira Franco (1907), Domingos Mascarenhas (1907), Jorge de Moraes (1908), Lyra Castro (1910) e Justiano Serpa (1911). Documentos, 1915, pp. 6-120.

${ }^{42}$ Coleção, 1916, p. 7. 
a defesa econômica da borracha, excetuados os accôrdos com os Estados que a produzem, a discriminação e legalização das posses de terras no território do Acre". ${ }^{43}$ Este seria o argumento inicial do chamado Plano de Defesa da Borracha. Na literatura, este plano foi apresentado como um grande projeto de transformação da região, envolvendo investimentos em transporte, redução de impostos, imigração, educação, saúde entre outros setores, mas que não se efetivaria. ${ }^{44}$ Um plano que se confundia com um "verdadeiro programa de desenvolvimento socioeconômico para toda a região amazônica", um "plano pluri-setorial", de "metas tão ambiciosas" ${ }^{45}$

A verdade é que tardiamente emergia um plano em nível federal que buscava resolver uma série de questões que afligia a economia do látex. A questão da produção asiática não era nova. Em 1900, por exemplo, o diretor do Jardim Botânico do Rio de Janeiro, João Barbosa Rodrigues, alertava para a necessidade de se passar da coleta extrativa para o cultivo intensivo da borracha, o que seria a possível forma de fomentar a produção nacional contra a concorrência britânica na Ásia. ${ }^{46}$ Contudo, como as exportações nacionais ainda perfaziam cerca de $60 \%$ da oferta mundial, a mobilização em torno de melhorias da atividade da goma elástica foi quase inexistente.

Somente pouco antes da promulgação do Plano, em 1910, que realizou-se em Manaus o "Primeiro Congresso Comercial, Industrial e Agrícola", reunindo representantes do Pará, Mato Grosso, Acre, Perú, Colômbia, Venezuela e Bolívia junto com seringalistas, comerciantes e exportadores da região amazônica. ${ }^{47}$ A reunião tinha por intenção debater o futuro da atividade extrativa e com um núcleo central de discussão: estimular o cultivo da hevea brasiliensis, secundados pela redução de impostos de exportação e importação. Antes de tudo, é preciso assinalar que o estado do Amazonas tinha se antecipado em relação ao incentivo ao plantio com as leis núm. 322, de 18 de setembro de 1900, estabelecendo "prêmio de dois contos de réis ao criador ou agricultor que plantasse e tivesse, em estado de florescer, 1000 cafeeiros ou cacaueiros, ou 2000 seringueiras" ${ }^{\text {" }}$ e com a lei núm. 503, de 1906 que oferecia "prêmio especial de dez contos" para 20000 seringueiras.

${ }^{43}$ Para os decretos núms. 2.543 e 9.521, em Coleção, 1916, vol. 1, pp. 7-12, e vol. 2, pp. 87-119.

${ }^{44}$ Para as discussões em torno do Plano de Valorização da Borracha, ver Benchimol, Estrutura, 1966, pp. 156-163; Prado \& Capelato, "Borracha", 1975, pp. 302-305, e Loureiro, Grande, 1985, pp. 89-102.

${ }^{45}$ Ver Pinto, Política, 1984, p. 49; Santos, História, 1980, p. 247, e Weinstein, Borracha, 1993, p. 257, respectivamente.

${ }^{46}$ Dean, Luta, 1989, p. 75.

${ }^{47}$ Ver Weinstein, Borracha, 1993, p. 255; também, Revista da Associação Comercial do Amazonas (ACA), núm. 13, 1909, en Loureiro, Grande, 1985, p. 77.

${ }^{48}$ Loureiro, Grande, 1985, p. 43. 
Não obstante, essas medidas paravam nas próprias ações da cadeia de extração da goma. Para os investidores não havia porque ampliar a produtividade do cultivo se os custos de extração da goma eram bastante reduzidos e uma transformação abrupta na estrutura de produção, com a formação de plantações intensivas de seringueiras exigiria custos mais elevados -e risco- que possivelmente não estavam em jogo para os seringalistas e nem para os seringueiros. Os seringueiros, por sua vez, para aumentar a capacidade de produção, necessitavam de normatização do trabalho que introduziria o assalariamento, assistência sanitária, redução de horas de trabalho, alimentação adequada, suprimentos de materiais fornecidos pelos seringalistas a menores custos, descanso semanal dentre outros elementos reorganizadores das condições de produção; somado a isso, para os seringalistas, estabelecer melhorias nas condições de trabalho, significava abrir mão de lucros exorbitantes extraídos dos débitos das mercadorias adquiridas pelos seringueiros ${ }^{49}$ e renegociar os investimentos com as casas aviadoras. Em outras palavras, as plantações exigiriam tempo para uma efetiva reformulação na base econômica dos seringais. Seringalistas, aviadores (intermediários), exportadores e importadores, cada qual com uma parte na absorção dos lucros, acomodaram-se na tentativa de incorporar tais mudanças. Estimulavam assim que investidores estrangeiros e nacionais como os administradores estaduais permanecessem de braços cruzados.

As primeiras medidas efetivas para estimular a exportação de borracha -o que poderia favorecer mudanças dentro das produções- apareceriam em fins da primeira década do século Xx. Em 1908, o Banco do Brasil passou a financiar a atividade extrativa (para aviadores e seringalistas) a juros subsidiados. Pouco mais tarde, organizou-se, em 1910, a Liga dos Aviadores, também com o apoio do Banco do Brasil, para auxiliar a formação de estoques regionais. No ano seguinte, Pará e Amazonas tentaram fundar dois bancos com recursos externos para destinar financiamento para a mesma atividade, mas o governo federal não consentiu a tomada

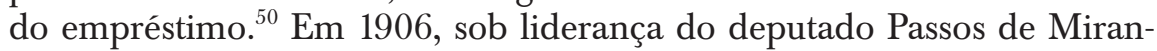
da, chegou-se a propor estímulos para a produção heveícola por meio da plantação das seringueiras de melhor qualidade, encampado pelo deputado Miguel Calmon du Pin e Almeida,$^{51}$ mas que gerou poucas medidas

49 “Convida realmente á meditação uma tal desproporção que varia, para uma mesma quantidade de mercadoria desde $354 \$$, seu custo no Rio de Janeiro, a $389 \$ 375$ no Pará, passando a $720 \$ 888$ no Acre, para ser facturada ao miserável seringueiro por 1: $386 \$ 635$ ". Documentos, 1915 , p. 402.

${ }^{50}$ Pinto, Política, 1984, p. 45, e Loureiro, Grande, 1985, pp. 111-115.

${ }^{51} \mathrm{O}$ deputado havia viajado para acompanhar as produções asiáticas. 
efetivas. A ida de Jacques Huber, diretor do Museu Goeldi do Pará, para a Ásia, teria sido uma das únicas ações para melhor a produção local. ${ }^{52}$

O governo do Pará teria promulgado uma lei que reduzia às taxas de exportação para 50\% em 1909, assim como as tarifas ferroviárias e, ainda, garantias de juros de 5\% sobre metade do capital aplicado em novas produções. Entretanto, como ressalta Warren Dean, mediante as finanças estaduais arrasadas, era difícil imaginar que o plano pudesse sair do papel. Ademais, no ano seguinte, uma conferência em Manaus reuniria cerca de 70 líderes do setor, exigindo a retomada de novas plantações, todavia, novamente sem sucesso. ${ }^{53}$

Liderando esse processo de necessária mudança das condições do extrativismo local, as associações comerciais do Amazonas e Pará se mobilizariam para tentar reverter o suposto atraso da economia regional. ${ }^{54}$ Sylvio Mário Puga Ferreira chega a afirmar que finalmente Pará e Amazonas se entenderiam em torno de uma questão comum, depois de episódios litigiosos em torno das rendas da borracha, agora defenderiam juntos a economia da borracha, mesmo que fosse por pouco tempo. ${ }^{55} \mathrm{Em}$ suma, a mobilização dos representantes estaduais refletiria em resultados em 1912. Momento em que o ministro da Agricultura, Indústria e Comércio, Pedro de Toledo, promulgaria a criação da Superintendência da Defesa da Borracha, com a nomeação do engenheiro Raymundo Pereira da Silva para seu superintendente. ${ }^{56}$ Nascia então o Plano de Defesa da Borracha.

O Plano de Defesa da Borracha, como plano de desenvolvimento econômico para a região, envolvia investimentos em transporte, construção de vias férreas, saneamento do Valle amazônico, redução dos impostos de exportação e dos fretes, limpeza dos rios, melhoramentos da produção e comercialização e imigração. De imediato foram declarados isentos os impostos de importação para os utensílios destinados à cultura e beneficiamento e o governo se comprometia em: "entrar em acordo com os estados do Pará, Amazonas e Mato Grosso, no sentido de obter a redução anual de $10 \%$ até o limite máximo de $50 \%$ do valor atual dos impostos de exportação cobrados pelos Estados sobre a borracha seringa". ${ }^{57}$ A grandeza do Plano de Defesa da Borracha já parecia carregar consigo sua inviabilidade.

${ }^{52}$ Pinto, Política, 1984, p. 45, e Castro, Sanjad e Santos, "Pátria", 2009.

${ }^{53}$ Dean, Luta, 1989, p. 79.

${ }^{54}$ Com a crise econômica em evidência a partir da década de 1910 é perceptível uma maior mobilização do setor local em busca de soluções para melhorar as condições de produção da borracha. Por exemplo, em 1913 a Associação Comercial do Amazonas publicaria o texto Cultura e exploração da borracha no Valle do Amazonas, uma cartilha para produtores narrando experiências asiáticas e estratégias para ampliar a produtividade local. Ver Castro, Cultura, 1913.

${ }^{55}$ Ferreira, Federalismo, 2007.

${ }^{56}$ Ministério, 1914.

${ }^{57}$ Decreto núm. 2.543, artigo núm. 12, Coleção, 1916, vol. 1, p. 11. 
No mais, o artigo $2^{\circ}$ do plano era instituído prêmios para plantações novas de seringueira que fossem tratadas regularmente: 2500 contos de réis para cada doze hectares de nova cultura de seringueira, e menores para as plantações de caucho, maniçoba e mangabeira. E prêmios semelhantes para replantios de 25 hectares. Para auxiliar as novas plantações, ou o melhor tratamento das antigas, o governo se propunha no artigo $3^{\circ}$, estabelecer uma estação experimental de cultura de seringueira, mas curiosamente, não apenas nos estados tipicamente produtores, como Amazonas e Pará (ou mesmo o território do Acre), como também no Mato Grosso, Maranhão, Piauí e Bahia. ${ }^{58}$

Para auxiliar a formação da mão de obra para a economia, seguindo os exemplos dos estados do Sudeste, o governo, no artigo $5^{\circ}$, criaria três hospedarias para imigrantes, em Manaus, Belém e, inclusive, no território do Acre, além de hospitais e colônias agrícolas sob responsabilidade da União. Para facilitar a comunicação da região, o governo daria continuidade à expansão ferroviária, como, por exemplo, fazendo a ligação de Belém com Minas Gerais e melhorias na navegação da região, com isenção na importação de embarcações. $O$ transporte regional, considerado como precário, era formado naquele período pela Estrada de Ferro Bragança, com construção entre 1883-1908, ligando Belém a região bragantina e a ferrovia Madeira-Mamoré construída como parte dos acordos de anexação do território do Acre entre 1907-1912. Como é sabido, esta se transformou numa ferrovia fantasma. ${ }^{59}$ Ademais, no que diz respeito às ligações fluviais existiam as empresas de navegação como Lloyd Brasileiro, que apesar dos estímulos, mantinham fretes cada vez mais proibitivos.

É curioso observar como um programa de tamanha monta teria sido aprovado "por unanimidade" na Câmara dos Deputados. A hipótese de Nelson Alves Prado Pinto é de que este plano fazia parte de uma estratégia de Hermes da Fonseca para obter apoio ao governo num momento delicado ${ }^{60}$ Vale lembrar que a cidade de Manaus foi bombardeada em 1910, em decorrência de divergências entre as oligarquias locais. Todavia, em poucos meses após sua aprovação, o projeto seria barrado no mesmo Congresso onde fora aprovado com facilidade. Francisco Glicério, por exemplo, questionava os custos elevados que essas medidas ocasionariam aos cofres públicos, alegando "que esse conjuncto formidável de medidas acarretaria, animando-me a avalia-lo em 300000 contos de réis, no mínimo. [...] não será possível ao governo executar esse conjuncto de providencias,

\footnotetext{
${ }^{58}$ Decreto núm. 2.543, artigo núm. 3, Coleção, 1916, vol. 1, p. 8.

${ }^{59}$ Sobre a Madeira-Mamoré, ver Hardman, Trem, 1988.

${ }^{60}$ Pinto, Política, 1984.
} 
somente aquellas que não acarretassem grandes despezas?"61 $\mathrm{O}$ Congresso recusou-se votar em suas seguintes sessões os créditos que permitiriam a efetivação do plano. No entender de Pinto, que reforçou a versão de outros estudos existentes ${ }^{62}$ a articulação entre uma elite tradicional comprometida com a manutenção da estrutura social e o desinteresse da União, que se preocupava basicamente com a economia cafeeira, legou a economia da borracha ao abandono.

\section{Os limites políticos do Plano de Defesa da Borracha: QUEM PAGA A CONTA?}

Apesar da fácil aprovação do Plano de Defesa da Borracha, de maneira muito diferente do sucesso do Plano de Valorização do Café de 1906, os esforços do governo federal e estadual caducaram sem a efetivação de boa parte das intenções defendidas no projeto de lei. A crise da borracha brasileira no início do século XX não era novidade para qualquer personagem da época. A experiência paulista, pragmática na compra dos estoques excedentes de café, tinha demonstrado grande viabilidade na manutenção dos preços e da sustentação do café brasileiro no mercado mundial. Entretanto, o cenário agora com a borracha era outro. Não somente o Brasil vinha perdendo de maneira muito profunda a predominância produtiva no mercado mundial do látex -o que reduzia a capacidade do realizar uma política nos termos da defesa do café, pois a região não detinha o controle da oferta do produto- como também os grupos internos não pareciam estar muito coesos na construção de uma política no porte da apresentada pelo Decreto de 1912.

Neste sentido, para compreender o nulo andamento das questões na realização do Plano da Borracha, precisamos avaliar os debates contemporâneos em torno de sua aprovação e implementação. ${ }^{63}$ Destacando que a não implementação do projeto não foi obra individual do deputado Francisco Glicério, como alegava o deputado federal do Amazonas Luciano Pereira da Silva (1913), ou de uma virada de mesa do presidente Hermes da Fonseca, por não mais precisar do apoio dos estados do Norte. ${ }^{64} \mathrm{~A}$ pro-

${ }^{61}$ Discurso proferido na sessão de 8 de julho de 1912, em Documentos, 1915, p. 141.

${ }^{62}$ Santos, Historia, 1980, e Loureiro, Grande, 1985,

${ }^{63}$ Os debates sobre os projetos para defesa da borracha estão compilados em Documentos, 1915.

${ }^{64}$ Weinstein, Borracha, 1993, pp. 259-261. "A simpatia federativa de 1912 se converteu numa espécie de animosidade. [...] O novo ministro da agricultura mostrou inexplicável irritação a proposito de programas de agricultura e colonização na Amazônia”, em Santos, História, 1980, p. 255. Já Antônio Loureiro salienta a "omissão do governo Federal, na tomada de providências 
blemática que devemos desmembrar é justamente como foi colocado o projeto em pauta e como ele foi encaminhado ao longo da década de 1910, quando a crise da borracha chegaria num ponto decisivo. Afinal, quais seriam os custos do Plano de Defesa, e como seria repartido esse ônus?

Para tanto, é preciso lembrar que o Plano de Valorização do Café, muito rememorado pelos políticos amazonenses contemporâneos, tratou "de duas questões interdependentes, mas distintas: a valorização do café e a estabilização da taxa cambial" ${ }^{65}$ Em outras palavras, tratava-se de um diálogo intenso entre os governos estaduais produtores de café com relação aos estoques da mercadoria, com o governo federal envolvendo a política econômica nacional. E, por isso mesmo, apesar da aparente facilidade em que o projeto foi aprovado na Câmara dos Deputados (106 votos a favor, contra quinze) e no Senado (31 contra seis) ${ }^{66}$ o Plano de Valorização do Café ao colocar em risco a estabilidade econômica conquistada pelas reformas de Campos Sales e Joaquim Murtinho de 1898, seria assunto de grandes embates entre 1905 e 1906. Como acentuou Thomas Holloway, apesar de uma presença maciça de representantes paulistas no executivo federal, autorizando a execução do plano, o governo da União não assumiria os custos pela compra dos estoques, ${ }^{67}$ já que pretendia deixar o milréis seguir o curso previsto de valorização. No final das contas, a solução foi colocada em prática somente com Afonso Pena na presidência e com o desmembramento do plano: São Paulo assumiria os empréstimos com o capital internacional para a compra dos estoques, enquanto o governo federal formaria a Caixa de Conversão para inserir o país no padrão-ouro. ${ }^{68}$

Assim, para pensar no Plano de Defesa da Borracha é necessário levar em conta justamente como este seria financiado e quais seriam as implicações destas escolhas para a economia nacional. Na documentação parlamentar compulsada encontramos os congressistas regionais mais preocupados com os "methodos de trabalho que nos herdaram os omaguas, os quaes methodos de trabalho [...] ficam muito aquém dos utilizados em Ceylao. [...] A organização do commercio da borracha encerra vícios mais profundos, e alguns, sem duvida, insanáveis". ${ }^{69}$ Ao invés de buscar medidas efetivas junto ao governo federal para pôr um fim a crise ou ao menos amenizá-la.

\footnotetext{
para conter a especulação e, depois, a derrocada dos preços, deixando a região ao desamparo". Loureiro, Grande, 1985, p. 69.

${ }^{65}$ Delfim, Problema, 2009, p. 62.

${ }^{66}$ Perissinotto, Classes, 1994, pp. 235-236.

${ }^{67}$ Holloway, Vida, 1978, p. 60.

${ }^{68}$ Ibid., pp. 63-65.

${ }^{69}$ Documentos, 1915, p. 36. "Discurso proferido por Passos de Miranda em 1906".
} 
O deputado Passos de Miranda no ano de 1906, por exemplo, antes mesmo do Plano de Defesa ser concebido, elencava uma série de gargalos na produção da borracha. De um lado aparecia a questão do trabalhador: declarava que a exploração excessiva do seringueiro, o trabalhador escasso e "caro" se comparado ao trabalhador asiático e o alto preço dos mantimentos ${ }^{70}$ ampliavam os custos da produção. De outro lado, para o autor, os valores dos fretes, os exorbitantes impostos de exportação, a falta de desenvolvimento de crédito e o numerário insignificante, ${ }^{71}$ limitavam a expansão das atividades econômicas na região. E claro, como argumento comum ao período, a especulação mercantil teria levado a região à crise ${ }^{72}$ e a apontava como medidas imediatas para saná-la, a redução dos impostos de exportação, redução dos preços dos transportes e a "alimentação sadia e acessível aos recursos do operário". ${ }^{73}$

Já no ano da promulgação do Plano de Defesa da Borracha, em 1912, o deputado amazonense Luciano Pereira sugeria que a "carestia de vida no Valle do Amazonas" era uma das principais razões da crise e, as causas dela seriam os altos impostos de importação e exportação, em especial as taxas cobradas sobre os "generos de primeira necessidade", somados a

irregularidade, difficuldade e sobretudo carestia extrema dos transportes. A essas causas principaes vem se juntar outras subsidiarias; umas devidas a condições especiaes do meio e outras decorrentes das duas principaes -taes a insalubridade de certas zonas, a falta de capitães, o atrazo dos seringueiros que não sabem tirar proveito dos preciosos recursos que estão ao seu alcance, etc., etcetera. ${ }^{74}$

No ano seguinte, outro parlamentar, Pereira Teixeira, ${ }^{75}$ assinalava os motores da crise na região norte como, ausência de circulação de moedas, a especulação no mercado financeiro e a alta dos preços dos produtos de consumo. Em decorrência de tais questões, propunha o combate a concorrência pela imitação da atividade asiática, ou seja, redução dos custos da produção e de cultivo, além da criação de um Banco exclusivo para as operações do comércio do látex.

Após as tentativas fracassadas para resolução da crise, em 1913 o deputado José Bonifácio ${ }^{76}$ entrou com um requerimento para que fosse nomea-

${ }^{70}$ Ibid., p. 37.

${ }^{71}$ Ibid., p. 102.

${ }^{72}$ Ibid., p. 110.

${ }^{73}$ Ibid., pp. 104-105.

${ }^{74}$ Silva, Defesa, 1913, p. 300.

${ }^{75}$ Discurso proferido na sessão de 27 de setembro de 1913. Documentos, 1915, pp. 298-303.

${ }^{76}$ Requerimento submetido a voto na Câmara dos Deputados na sessão de 26 de agosto de 1913. Documentos, 1915, pp. 380-390. 
da uma nova comissão para estudar "a verdadeira situação da indústria nacional da borracha" e aconselhar o que seria "conveniente para salvaguarda dos interesses geraes do paiz". ${ }^{77}$ Evidenciava-se que o Plano de Defesa, apesar de sua magnitude, pouco avançava.

Em dezembro daquele ano de 1913 foi criada a Comissão Especial Mista da Defesa da Borracha, tempos depois da promulgação do Plano de Defesa da Borracha. Composta agora pelos senadores Francisco Glycerio, Feliciano Penna, Francisco Sá e deputados Eloy de Souza, Antonio Carlos e Homero Baptista, buscava elaborar um parecer final sobre a crise da economia de exportação da borracha e sugerir medidas práticas e eficazes para o problema. Em relatório a comissão apontou como geradores da crise: "incapacidade administrativa [...] de havermos permittido a concurrencia do producto similar estrangeiro". ${ }^{78}$ Ademais, arrolavam todas as mazelas do regime de trabalho: as doenças nos seringais, o regime de servidão no trabalho e a resistência dos seringueiros ao sistema de crédito "lesivo", pois o seringueiro não saldava suas dívidas devido aos elevados preços dos gêneros de abastecimento. E, reiteravam, as longas distâncias das áreas de produção, as dificuldades na forma de comercializá-la, os altos fretes, a obstrução dos rios e a ausência de vias férreas. A comissão, em parte, se eximia das culpas, considerando que o desinteresse dos dois estados nortistas, que "nada fizeram pela indústria", teriam criado tal situação de abandono. ${ }^{79}$

Mediante o exposto, o relatório propunha "os meios" para pôr fim a "crise", por meio do saneamento da região, a redução dos impostos de exportação, assim como a necessidade de combater os altos valores dos fretes, por meio da construção de vias férreas. Estas seriam as medidas inadiáveis e prementes. É interessante notar que apesar do relatório apontar as péssimas condições de vida dos extratores -o que incluía alimentação insalubre, ausência de assistência sanitária, regime de servidão, sistema de crédito desonesto, sofrimento moral e outros-, não inseriu as melhorias de condições de trabalho como uma das soluções para "solver a crise", mesmo assinalando que este elemento era um dos fatores "permanentes de desvalorização do produto". ${ }^{80}$ É interessante ressaltar como esta versão do relatório, que certamente tocava em pontos cruciais da crise daquele momento, passou a ser absorvida com variantes pelas interpretações

${ }^{77}$ Ibid., p. 390.

${ }^{78}$ Ibid., p. 391.

${ }^{79}$ Ibid., pp. 396-420.

${ }^{80}$ Ibid., p. 406. 
posteriores: ${ }^{81}$ a questão da precária infraestrutura, das relações de trabalho "pré-capitalistas" e a própria concorrência internacional.

Vale notar que o relator Eloy de Souza, também em 1913, sinalizou ao longo de sua exposição às barreiras para efetivação do plano. Talvez de maneira bastante realista, percebia uma economia regional num estado de crise estrutural e um custo nacional para efetivação do plano e recuperação da atividade que fugia em muito da capacidade do governo federal. Argumentava Eloy de Souza, em primeiro lugar, a dificuldade para se encontrar um "justo equilíbrio" com a concorrência internacional. Em segundo lugar, admitindo a impossibilidade de "aconselhar o Congresso a incidir no erro de pretender dar solução a um plano de tamanho vulto", ${ }^{82}$ considerava criminoso o uso do erário público para fins contraproducentes. E, por fim, salientando que as despesas para execução do Plano de Valorização da Borracha redundariam em "250 000 contos", sabia que tal montante levaria ao recuo até seus defensores.

Era certamente um valor elevado. A título de comparação, entre 1906 e 1907, somente o estado de São Paulo despendeu 7200000 libras (e estava autorizado a contratar 15000000 de libras) para o seu Plano de Valorização do Café, o equivalente a mais de 100000 contos de réis. Era um valor elevado, e vale lembrar, não aceito também pelo governo federal. ${ }^{83}$ Portanto, o suposto descaso do governo federal com a Amazônia, talvez não tenha sido o maior vilão da crise da borracha: para São Paulo, o governo federal também não tinha assumido tamanho compromisso financeiro. O plano regulamentado no Decreto núm. 9.521 de 17 de abril de 1912, revelou ser inexequível. No exterior dificilmente seriam encontrados banqueiros interessados em investir na produção amazônica -não somente os dois estados nortistas tinham menores recursos do que São Paulo para garantir tais empréstimos, como a borracha brasileira perdia rapidamente seu papel no mercado internacional. Os déficits orçamentários do governo federal tinham colocado em cheque o interesse dos credores internacionais, que reduziam o fluxo de capital para o Brasil a partir de $1912 .{ }^{84}$ No que diz respeito aos recursos nacionais, o governo federal, inclusive seguindo o exemplo do Plano de Valorização do Café já tinha deixado claro que não investiria em projetos tão amplos de intervenção econômica. A estabilidade gerada pela Caixa de Conversão, um consenso ortodoxo no Ministério da Fazenda, impediria uma política tão ampla quanto à exigida pela defesa da borracha.

${ }^{81}$ Ver Weinstein, Borracha, 1993; Cano, Raízes, 1977; Cardoso e Müller, Amazônia, 1977; Carone, República, 1975, e Dean, Luta, 1989.

${ }^{82}$ Documentos, 1915, p. 418.

${ }^{83}$ Delfim, Problema, 2009, p. 64.

${ }^{84}$ Fritsch, "Apogeu", 1989, p. 40. 
Parece evidente que a defesa da borracha precisava lidar de início com uma questão maior do que as variáveis controladas pelo governo federal. Com a participação decisiva dos comerciantes estrangeiros no setor, a especulação financeira das bolsas de Londres e Nova York, ${ }^{85}$ assim como a crescente concorrência de empresas londrinas nos seringais asiáticos, reduziam ao mínimo qualquer tentativa de sucesso do plano. Por isso mesmo que os recursos do Tesouro pareciam ser insuficientes, afinal, o plano tentava abarcar as mais variadas frentes:

reduç̧ão do custo dos utensilios e materiaes empregados na exploração da industria de borracha; premios em dinheiro aos cultivadores das principaes arvores productoras de borracha; estações experimentaes para cultura da borracha; creação das industrias de refinação e de fabricação de artefactos de borracha; assistencia aos immigrantes nacionaes e estrangeiros recém-chegados e aos trabalhadores já estabelecidos no Valle do Amazonas; hospitaes interiores; núcleos agrícolas adjacentes aos hospitaes; melhoramentos e medidas tendentes a facilitar os transportes e diminuir o seu custo no Valle do Amazonas; melhoramentos da navegabilidade dos rios Branco, Negro, Purus e Acre; creação de centros productores de gêneros alimentícios no Valle do Amazonas. [...] colonização das terras da fazenda de S. Marcos situadas entre os rios Mahú, Takutú, Surumú e Cotingo; premios favores aos que pretendem fundar grandes fazendas de agricultura e criação; favores a uma empreza de pesca; exposições triennaes abrangendo tudo o que se relaciona com industria da borracha nacional; direção e fiscalização dos serviços. ${ }^{86}$

Podemos avaliar que a diminuição das despesas com utensílios usados na exploração da borracha já ocorria porque frequentemente extratores faziam uso de uma lanterna, uma faca e às vezes uma machadinha, material barato e custeado por eles próprios. Premiar os cultivadores na região era impraticável: no Amazonas e Pará já se pagavam pequenos investidores de plantação da seringa em alguns municípios ${ }^{87} \mathrm{O}$ plantio em grandes proporções, por outro lado, já tinha sido abandonado pelos próprios extrativistas: a passagem da extração para a produção recebia pouca atenção dos comerciantes. A criação de estações experimentais projetada para cultivo da seringueira iria além da região norte, alcançando Mato Grosso, Maranhão, Piauí e Bahia, acrescida de estações para cultura de mangabeira e maniçoba nos estados de Piauí, Ceará, Pernambuco, Bahia, Minas Gerais, São Paulo, Goiás, Paraná e Mato Grosso. Enfim, já se ultrapassava o problema regional: para cada estação seriam implantados laboratórios de

${ }^{85}$ Loureiro, Grande, 1985 , p. 65

${ }^{86}$ Coleção, 1916, vol. II, pp. 86-118.

${ }^{87}$ Loureiro, Grande, 1985, p. 43. 
fisiologia vegetal, entomologia agrícola, química agrícola, microbiologia e tecnologia agrícola; um museu agrícola e florestal; galeria de máquinas e posto metereológico.

Outro ponto comum nos debates sobre a defesa da borracha era a criação de indústrias de refinação e de fabricação de produtos de borracha em Manaus e Belém. Propunham-se estímulos como as premiações de "até 400:000\$ em dinheiro para usinas de refinação de borracha seringas; até 100:000\$ em dinheiro para usinas de refinação de borracha de maniçoba e mangabeira; até 500:000\$ em dinheiro pra as fabricas de artefactos de borracha" ${ }^{88} \mathrm{~A}$ impossibilidade de custear essas premiações não exigem muitos cálculos, mas o mais difícil era encontrar empresários interessados em realizar tais investimentos, num momento em que a produção asiática conquistava os principais mercados consumidores.

Para o problema da falta de mão-de-obra era aventada a imigração. A construção de hospedarias em Belém, Manaus e o território do Acre seriam instaladas e mantidas pela União com intuito de atrair imigrantes e migrantes. Tais empreendimentos, porém, não saíram do papel. ${ }^{89}$ Os hospitais seriam construídos em Boa Vista do Rio Branco, São Gabriel do Rio Negro, Teffé ou Fonte Bôa, no rio Solimões, São Phillipe, no rio Juruá, Bocca do Acre, rio Purús, confluência dos rios Arinos e Juruena, no alto Tapajoz, Conceição do Araguaia e Montenegro no território do Amapá. Todavia, como garantir atendimento com tamanha sofisticação, com salas cirúrgicas, consultórios, salas de autopsias, farmácias e cercados por "nucleos agricolas", numa região marcada pela descentralização e dispersão devido tamanho território? Ademais, o plano sugeria a implantação de centros produtores de gêneros alimentícios com criação de gado e cultivo de cereais como forma de garantir o abastecimento local.

Ainda vale destacar que todos sabiam da precária situação do transporte, este como um dos grandes gargalos para a atividade na Amazônia. No artigo núm. 45, "das redes de viação ferrea", a sugestão era de que se construíssem no Valle do Amazonas, vias férreas de "grande viação" e de "viação econômica, de bitola reduzida" com caráter provisório, "caminhos" acessíveis para exploração de seringais novos. As vias férreas eram inviáveis não somente pelos altos custos, mas por certas condições geográficas de um território marcado por uma extensa bacia hidrográfica. A via férrea que iniciaria no Rio Abunan passaria por Vila Rio Branco, Sena Madureira e Catay e terminaria em Vila Thaumaturgo com ramal até o

${ }^{88}$ Coleção, 1916, vol. II, p. 93.

${ }^{89}$ Segundo: "há notícia de uma série de firmas internacionais atraídas para atuar, ou que solicitaram registro àquela altura a fim de assegurar-se no futuro a posse dos prêmios e vantagens [...] Não consta que qualquer dessas firmas haja promovido imigração.” Santos, História, 1980, pp. 252-253. 
Peru pelo rio Purus: seria uma obra de arquitetura grandiosa em região entrecortada por rios volumosos, inúmeros afluentes, terras alagadiças e técnicos despreparados para esse modelo de arquitetura. Sem falar da proposta de desobstrução dos rios Branco, Negro, Purús e Acre para torná-los navegáveis nas estações de chuvas e de vazante dos rios. As ferrovias, como projetos para a Amazônia, depois do complicado caso da Madeira-Mamoré, não seria uma prioridade para nenhum governo. As empresas de navegação, por outro lado, viam suas rendas caírem conforme a crise do látex era instaurada na região.

Por último, em parecer ao orçamento da receita geral da república para o exercício de 1915, Carlos Peixoto mencionava o "notável" relatório da Comissão Mista para por fim a crise, porém reconhecia que, "o Brazil não pôde dispor em 1915 de verba alguma para impedir a morte da indústria seringueira, a ruina definitivamente dos estados produtores e a completa e conseqüente desorganização do nosso comercio internacional" ${ }^{90}$ É preciso lembrar que, agora em 1915, com o cenário da Grande Guerra e a crise e fechamento da Caixa de Conversão brasileira, as condições financeiras do governo estavam deterioradas. $\mathrm{O}$ debate parlamentar foi exaustivo, as petições várias, o governo da União diligente ao menos nos decretos, mas este parecer antecipava o fim do Plano de Valorização da Borracha.

\section{CONSIDERAÇÕES FINAIS}

Muito mais ambicioso do que o Plano de Valorização do Café, o plano voltado para a recuperação da economia do látex articulava uma diversidade de ações, entre infraestrutura, questões sociais como saúde e formação profissional, assim como de povoamento da região. Contudo, diferente do acordo estabelecido no Convênio de Taubaté, as condições objetivas para o país sustentar o preço internacional da borracha era exíguas. Projetos e intenções para alterar a dinâmica da economia nortista vinham em debate desde o início do século Xx. As críticas ao cenário contraditório de uma abundante construção de prédios em Manaus e da desatenção com o extrativismo do látex e da geração de "novos mananciaes de receita" também era lembradas. Foi somente quando a crise tornou-se crítica que finalmente a lei de defesa foi decretada.

O plano previsto no regulamento núm. 9.521 continha sete títulos e 114 artigos e sua execução seria dirigida e fiscalizada pela Superintendência da Defesa da Borracha. Para os contemporâneos como o deputado

\footnotetext{
${ }^{90}$ Documentos, 1915 , p. 558.

${ }^{91}$ Guapindaya, Amazonas, 1900, p. 11.
} 
amazonense Luciano Pereira da Silva, ${ }^{92}$ não menos que irmão do superintendente Raymundo Pereira da Silva, o plano apesar de ter tido curta duração de "um ano e cinco mezes e dezoito dias", funcionando somente como uma repartição pública e sem atividades efetivas, trouxe "grandes serviços ao nosso paiz". Nas palavras de Luciano Pereira, o plano organizou repartições, diminuiu o imposto de exportação, criou uma lei de terras para o território do Acre, regulamentou a marinha mercante de cabotagem, elaborou estudos sobre a navegação no rio Branco, sobre a criação das estações experimentais, e sobre as hospedarias de imigrantes de Manaus e Belém. Contudo, como bem lembra Roberto Santos, com um olhar mais distante e acurado: "o Plano fracassou em todos os setores". ${ }^{33}$

A crise da economia da borracha no Brasil se colocou num momento em que a concorrência asiática apostava num novo processo produtivo e assegura o controle do mercado mundial. A crise dos estados do Amazonas e Pará, mais do que uma crise de um setor econômico da região, materializava-se num modelo de produção extrativista e exportador, cuja vulnerabilidade era intrínseca. Os discursos parlamentares, os projetos, os relatórios e o próprio regulamento que instituiu a Superintendência da Defesa da Borracha não contestavam essa limitação. Com um desafio quase impossível de reverter a posição de produtor mundial da borracha, os políticos locais buscaram no plano de defesa o meio para superação das mais diversas questões regionais, entretanto, sem qualquer transformação na estrutura social. A defesa da borracha tornava-se, portanto, um Plano de Desenvolvimento Regional para sustentação das elites econômicas locais. Por outro lado, no cenário nacional, as elevadas despesas para a execução deste plano eram incompatíveis com o recurso financeiro disponível e, especialmente, com o projeto político-econômico de cunho ortodoxo do país. Neste sentido, se regionalmente o plano reforçava um modelo econômico em crise e nacionalmente não se colocava nenhum esforço de mudança de direção, o plano não poderia resultar em nenhum resultado efetivo. Com um plano sem apoio econômico federal; sem transformações das hierarquias regionais; sem capacidade de concorrer na economia internacional, a produção da borracha certamente não poderia desempenhar mais o papel de antes.

${ }^{92}$ Silva, "Defesa", 1913, pp. 581-594.

${ }^{93}$ Santos, História, 1980, p. 251. 


\section{FONTES CONSULTADAS}

Andrade, Jorge, Panorama econômico-financeiro do Amazonas, Manaus, Edições do Governo do Estado do Amazonas, 2001 (fac-símile de 1939), (Coleção Documentos da Amazônia, num. 41).

Anuário estatístico do Brasil, ano v, 1939-1940, Rio de Janeiro, Instituto Brasileiro de Geografia e Estatística/Confederação Nacional de la Industria, 1986, vol. 1.

Benchimol, SAmuel, Estrutura geosocial e econômica da Amazônia, Manaus, Edições do Governo do Estado do Amazonas, 1966.

Bittencourt, Agnello, Corographia do estado do Amazonas, Manaus, Aca/Fundo, 1985. Cano, Wilson, Raizes da concentração industrial em São Paulo, Rio de Janeiro, Difel, 1977. , Raízes da concentração industrial em São Paulo, São Paulo, Campinas, Universidad de Campiñas, 4a. ed., 1988.

Cardoso, Fernando e Geraldo Müller, Amazônia: expansão do capitalismo, São Paulo, Brasiliense, 1977.

Carone, Edgard, A república velha I (Instituições e classes sociais), São Paulo, Difel, 3a. ed., 1975.

Carneiro, Domingues, A borracha e sua desvalorização, Belém, s. e., 1918.

Catramby, G., A cultura da seringueira. Publicação feita por ordem de s. Exca. O Sr. Dr. Antonio Constantino Nery governador do Estado, Manaus, Secção de Obras da Imprensa Official, 1907.

Castro, Anna Raquel de Matos, Nelson Sanjad e Doralice dos Santos RomeiRO, "Da pátria da seringueira à borracha de plantação: Jacques Huber e seus estudos sobre a cultura das heveas no Oriente (1911-1912)”, Boletin do Museu Paraense Emílio Goeldi. Ciências Humanas, vol. 4, núm. 3, diciembre de 2009, Belém.

Castro, Raymundo C. Monteiro de, Cultura e exploração da borracha no Valle do Amazonas, Manaus, Associação Comercial do Amazonas, 1913.

Coleção de Leis da Republica dos Estados Unidos do Brazil de 1912, Rio de Janeiro, Imprensa Nacional, 1916, vols. I y II.

Colton, G. W., Colton's Atlas of the World Illustrating Physical and Political Geography, Nueva York, G. W. \& C. B. Colton \& Co., 1855, vol. 1.

Costa, Francisca Deusa S. DA, "Quando viver ameaça a ordem urbana: trabalhadores urbanos em Manaus (1890-1915)”, mestrado em História, São Paulo, Pontifícia Universidade Católica, 1997.

Dean, Warren, A industrialização de São Paulo, São Paulo, Difel, 1971. bel, 1989.

Delfim Netto, Antonio, O problema do café, São Paulo, Universidad Estatal Paulista, 2009.

Dias, Edinea Mascarenhas, A ilusão do Fausto: Manaus, 1890-1920, Manaus, Valer, 2a. ed., 2007. 
Am. Lat. Hist. Econ., año 20, núm. 3, septiembre-diciembre, 2013, pp. 138-169

Documentos parlamentares. Política econômica. Defesa da Borracha: 1906-1914, Rio de Janeiro, Typ do Jornal do Commercio, 1915.

Fausto, Boris, História geral da civilização brasileira, vol. 1, O Brasil Republicano, São Paulo, Difel, 1975.

"Expansão do café e política cafeeira" in FAUSTO Boris, História geral da civilização brasileira, São Paulo, Difel, 1985, vol. 3, t. I.

Ferreira, Sylvio MÁrio Puga, Federalismo, economia exportadora e representação política: o Amazonas na república velha (1889-1914), Manaus, Universidade Federal do Amazonas, 2007.

Fritsch, Winston, “Apogeu e crise na Primeira República: 1900-1930” in Marcelo de Paiva Abreu, A ordem do progresso, Rio de Janeiro, Campus, 1989.

Furtado, Celso, Formação econômica do Brasil, São Paulo, Companhia Editora Nacional, 27a. ed. rev., 1990.

Guapindaya, Fernando, O Amazonas. Os escandalos da administração do Sr. José Ramalho Junior, Rio de Janeiro, Diário de Noticias, 1900.

Hardman, Francisco Foot, Trem fantasma: a modernidade na selva, São Paulo, Cia das Letras, 1988.

Holloway, Thomas, Vida e morte do Convênio de Taubaté: a primeira valorização do café, Rio de Janeiro, Paz e Terra, 1978.

Huber, JaCQUes, Relatório sobre o estado actual da cultura da Hevea brasiliensis nos principais paizes de producção do Oriente, Belém, Imprensa Official do Estado, 1912.

LEONARDI, VICTOR P. B., Os historiadores e os rios: natureza e ruína na Amazônia Brasileira, Brasília, Paralelo 15/Universidade de Brasilia, 1999.

Leis, decretos e regulamentos, t. XI (janeiro a dezembro de 1910), Manaus, Secção de Obras da Imprensa Official, 1911.

Lino Aguiar \& Cia., Almanach do Amazonas de 1908, Manaus, Palais Royal, 1909.

Lloyd, Reginald, Impressões do Brasil no século XX, Londres, Lloyd's Greater Britain Publishing Companhy Ltd., 1913, em <http://www.novomilenio.inf.br/santos/ h0300g31.htm >, [Consulta: 29 de agosto de 2012].

Loureiro, Antônio José Souto, Síntese da história do Amazonas, Manaus, Imprensa Oficial, 1978.

A grande crise (1908-1916), Manaus, T. Loureiro \& Cia., 1985.

Tempos de esperança-Amazonas 1917-1945, Manaus, Sérgio Cardoso, 1994.

Mendes, J. A., “A cultura da Hevea no Oriente- Sua manufatura nos Estados Unidos”, palestra realizada no Theatro da Paz na noite de 25 de março de 1911, terminada com um discurso do Exmo. Sr. Dr. Jacques Huber, diretor do Museu Goeldi do Pará, Belém, 1911.

Mensagem lida perante a Assembléa legislativa na abertura da terceira sessão ordinária da oitava legislatura pelo Exmo. Sr. Dr. Jonathas de Freitas Pedrosa governador do Estado em 10 de julho de 1915, Manaus, Seção de Obras da Imprensa Pública, 1915. 
Mensagem lida perante a Assembléa legislativa na abertura da primeira sessão ordinária da nona legislatura pelo Exmo. Sr. Dr. Jonathas de Freitas Pedrosa governador do Estado em 10 de julho de 1916, Manaus, Seção de Obras da Imprensa Pública, 1916.

Mensagem lida perante a Assembléa legislativa na abertura da segunda sessão ordinária da nona legislatura pelo Exmo. Sr. Dr. Pedro de Alcantara Bacellar governador do Estado em 10 de julho de 1917, Manaus, Seção de Obras da Imprensa Pública, 1917.

Ministério da Agricultura, Indústria e Comércio, ministro Pedro de Toledo, ano de 1911-1912, Rio de Janeiro, Imprensa Nacional, 1914, vol. 1.

Monteiro, Mario Y., Negritude E̊ modernidade: a trajetória de Eduardo Gonçalves Ribeiro, Manaus, Governo do estado do Amazonas, 1990.

Perissinotto, Renato, Classes dominantes e hegemonia na república velha, Campinas, Universidad Estatal de Campinas, 1994.

Pinheiro, M. Luiza UGarte, A cidade sobre os ombros: trabalho e conflito no porto de Manaus (1899-1925), Manaus, Editora da Universidade do Amazonas, 1999.

"Folhas do Norte: letramento e periodismo no Amazonas (1880-1920)", tese de doutorado, São Paulo, Pontifícia Universidade Católica, 2004.

Pinto, Nelson Prado Alves, Política da borracha no Brasil, São Paulo, Hucitec, 1984.

Prado JR., Caio, História econômica do Brasil, São Paulo, Brasiliense, 38a. ed., 1990. , Formação do Brasil Contemporâneo, São Paulo, Brasiliense, 23a. ed., 2004.

Prado, Maria lígia Coelho e Maria Helena Rolim Capelato, "A borracha na economia brasileira da Primeira República" em Boris FAusto, História geral da civilização brasileira, vol. 1, O Brasil Republicano, São Paulo, Difel, 1975.

Reis, Arthur CÉZAr F., A Amazônia e a cobiça internacional, Manaus, Edições Governo do Estado do Amazonas, 1965.

Rotina e dinâmica na vida brasileira, Manaus, Edições Governo do Estado do Amazonas, 1965.

, História do Amazonas, Belo Horizonte, Itatiaia/Universidade do São Paulo, 1989. 1997.

Relatórios da Secretaria da Fazenda do Estado de São Paulo (1900-1910), São Paulo, Secretaria dos Negócios da Fazenda, vols. 1900-1910.

Relatório apresentado ao Exm. Sr. Cel. Antonio Clemente Ribeiro Bittencourt governador do Amazonas por Cyrillo Leopoldo da Silva Neves inspector do Thesouro em Commissão. Anno de 1910, Manaus, Secção de Obras da Imprensa Official, 1911.

Santos, Eloína M., A rebelião de 1924 em Manaus, Manaus, Valer, 2001.

SANTOS JÚNior, PAUlo Marreiro dos, Vivência popular, exclusão e conflito social em Manaus 1906-1917, Manaus, Universidade Federal do Amazonas, 2004.

Santos, Roberto, História econômica da Amazônia (1800-1920), São Paulo, T. Queiroz, 1980 . 
Silva, Luciano Pereira, "Defesa econômica da Borracha", discurso pronunciado nas sessões de 10 de julho, 7 de agosto, 27 de setembro e 1 de outubro de 1912 da Câmara dos Deputados, Rio de Janeiro, Typ. do Jornal do Comercio, 1913.

WEINSTEIN, BARBARA, "Experiência de pesquisa em uma região periférica, a Amazônia”, História, Ciências, Saúde-Manguinhos, Fundação Oswaldo Cruz, vol. 9, núm. 2, maio-agosto, 2002, Rio de Janeiro, pp. 261-272.

, A borracha na Amazônia, expansão e decadência (1850-1920), São Paulo, Hucitec/Universidade de São Paulo, 1993. 